\title{
MicroRNA-21 in lung cancer: overexpression in metastasis of pulmonary adenocarcinomas and squamous cell carcinomas
}

\author{
Maria R Silva ${ }^{1,2 *}$, Paulo Santos ${ }^{2,4,5}$, Isabel Velada ${ }^{4}$, Catarina Gomes ${ }^{1}$, M João d'Aguiar ${ }^{1}$, Lia Teixeira ${ }^{1}$, João Dinis ${ }^{1}$, \\ Susana Carmona ${ }^{4}$, Luisa Cortes ${ }^{5}$, Lina Carvalho ${ }^{1,2,3,5}$
}

From 16th International Charles Heidelberger Symposium on Cancer Research

Coimbra, Portugal. 26-28 September 2010

MicroRNAs (miRNAs) are a class of naturally occurring small non-coding RNAs that target protein-coding mRNAs at the post-transcriptional level. Expression profiling has identified miRNA signatures in cancers that associate with diagnosis, staging, progression, prognosis, and response to treatment. MiRNAs are ideal biomarkers in FFPE-tissue because, unlike mRNA, miRNA integrity is affected very little by formalin fixation. Previous studies have shown that miR-21 overexpression correlated with poor prognosis in NSCLC patients.

In this study we investigated the expression of mir-21 in primary carcinoma and metastasis and near nontumor parenchyma.

FFPE samples from surgical specimens and biopsies of 7 pulmonary adenocarcinomas and 5 squamous cell carcinomas and respective metastasis together with normal lung tissue from the same case; these areas were separated by laser-capture microdissection prior to miRNA analysis.

The expression level of miR-21 by qRT-PCR was significantly higher in tumor tissues than in adjacent normal tissues $(\mathrm{p}=0.005)$. The overexpression in the metastasis samples compared to adjacent normal tissue was almost satistically significant ( $\mathrm{p}=0.051$ ).

MiR-21 was overexpressed in tumor tissues relative to adjacent non-tumor tissues. We found an increase in miR-21 expression in primary carcinoma and metastasis in pulmonary adenocarcinomas when compared with miR-21 lower expression in squamous cell carcinoma. Despite the small sample studied, further investigation may indicate therapeutic and prognostic relevance of

\footnotetext{
* Correspondence: mrsilva@fmed.uc.pt

${ }^{1}$ Instituto de Anatomia Patológica, Faculdade de Medicina da Universidade de Coimbra, Coimbra, Portugal

Full list of author information is available at the end of the article
}

this determination, previous studies suggest that miR-21 and has a role in tumor growth, invasion and metastasis by targeting multiple suppressor genes [1]. Therefore, suppression of miR-21 may provide a novel approach for the treatment of advanced cancers through regulation of tumour suppressor genes.

\section{Author details}

'Instituto de Anatomia Patológica, Faculdade de Medicina da Universidade de Coimbra, Coimbra, Portugal. ${ }^{2}$ Centro de Investigação em Meio Ambiente, Genética e Oncobiologia (CIMAGO), Coimbra, Portugal. ${ }^{3}$ Serviço de Anatomia Patológica dos Hospitais da Universidade de Coimbra, Coimbra, Portugal.

${ }^{4}$ Laboratory of Funcional Genomics, Centro de Histocompatibilidade do Centro, Coimbra, Portugal. ${ }^{5}$ Centro de Neurociências e Biologia Celular, Coimbra, Portugal.

\section{Published: 24 September 2010}

Reference

1. Zhu S, Wu H, Wu F, Nie D, Sheng S, Mo YY: MicroRNA-21 targets tumor suppressor genes in invasion and metastasis. Cell Res 2008, 18:350-359.

doi:10.1038/cr.2008.24

Cite this article as: Silva et al: MicroRNA-21 in lung cancer: overexpression in metastasis of pulmonary adenocarcinomas and squamous cell carcinomas. BMC Proceedings 2010 4(Suppl 2):P14.

Submit your next manuscript to BioMed Central and take full advantage of:

- Convenient online submission

- Thorough peer review

- No space constraints or color figure charges

- Immediate publication on acceptance

- Inclusion in PubIMed, CAS, Scopus and Google Scholar

- Research which is freely available for redistribution

Submit your manuscript at www.biomedcentral.com/submit 